\title{
Implementasi Kinematika Robot Lengan Pemindah Barang Dua Sendi (2 DOF) dengan Metode Kinematika Maju Untuk Menentukan Koordinat dalam Pemindahan Sebuah Object
}

\begin{abstract}
Alamsyah Syahiidutama, Departemen Teknik Elektro, Institut Sains dan Teknologi Terpadu Surabaya, Setya Ardhi, Departemen Teknik Elektro, Institut Sains dan Teknologi Terpadu Surabaya, Judi Prajetno Sugiono, Departemen Teknik Elektro, Institut Sains dan Teknologi Terpadu Surabaya, dan Hari Sutiksno, Departemen Teknik Elektro, Institut Sains dan Teknologi Terpadu Surabaya
\end{abstract}

\begin{abstract}
Abstrak- Pada industri rumahan minuman berwarna pekerja dituntut untuk dapat memilah botol berwarna secara cepat dan tepat. Untuk mengatasi masalah ini direncanakan dan dibuat alat pemilah botol berdasarkan warna dengan bantuan robot lengan. Sensor yang dipakai untuk pemilah warna menggunakan LED RGB dan resistor LDR yang mampu memilah 9 warna yaitu: merah, kuning, hijau, biru, merah muda, putih, ungu, sian, dan hitam dengan memanfaatkan robot lengan sebagai pemilah. Robot didesain yang diadaptasi dari robot lengan me arm v1.0 dengan dimensi $15 \mathrm{~cm} \times 19 \mathrm{~cm}$, dan tinggi $50 \mathrm{~cm}$. Untuk menjalankan alat ini botol berwarna diletakkan pada tempat sensor warna, setelah warna terdeteksi lengan robot akan bergerak mengambil dan meletakkan botol yang terdeteksi ke dalam wadah yang ditandai dengan reed switch (sensor magnet). Desain robot lengan menerapkan metode forward kinematic untuk mendapatkan titik koordinat robot. Percobaan untuk menentukan titik koordinat robot memberikan hasil sebagai berikut: $(19,15 \mathrm{~cm}, 8,92 \mathrm{~cm})$ saat istirahat, $(23,49 \mathrm{~cm}, 33,55 \mathrm{~cm})$ saat mengangkat botol, dan $(35,35 \mathrm{~cm}, 0 \mathrm{~cm})$ saat mengambil botol. Tingkat keberhasilan sensor warna dan lengan robot dalam memilah botol berdasarkan warna adalah sebesar $\mathbf{7 4 , 0 7 \%}$. Lama proses untuk melakukan pemilahan botol berwarna dengan beban $100 \mathrm{ml}$ adalah 40,2 detik untuk satu botol.
\end{abstract}

Kata Kunci-Forward Kinematic, Koordinat Robot, Reed Switch, Robot Lengan, Sensor Warna.

Maret 2020

Alamsyah Syahiidutama, Departemen Teknik Elektro, Institut Sains dan Teknologi Terpadu Surabaya, Surabaya, Jawa Timur, Indonesia (e-mail: alamsyahsu@gmail.com)

Setya Ardhi, Departemen Teknik Elektro, Institut Sains dan Teknologi Terpadu Surabaya, Surabaya, Jawa Timur, Indonesia, Surabaya, Jawa Timur, Indonesia (e-mail:setyaardhi@istts.ac.id)

Judi Prajetno Sugiono, Departemen Teknik Elektro, Institut Sains dan Teknologi Terpadu Surabaya, Surabaya, Jawa Timur, Indonesia (e-mail: jpsugiono@istts.ac.id)

Hari Sutiksno, Departemen Teknik Elektro, Institut Sains dan Teknologi Terpadu Surabaya, Surabaya, Jawa Timur, Indonesia, Surabaya, Jawa Timur, Indonesia (e-mail: harisutiksno@gmail.com)

\section{Pendahuluan}

$P$ ada bab pendahuluan berikut ini akan dijelaskan mengenai latar belakang permasalahan, tujuan yang ingin dicapai, ruang lingkup yang membatasi permasalahan yang dibahas, tahap penyelesaian. Robot merupakan pengendali sesuatu yang dapat diprogram, robot memiliki penggerak atau manipulator dan didesain untuk memindahkan barang, dan komponen robot berguna menyelesaikan suatu pekerjaan (engineering.nyu from Robot Institute of America, 1997).

Kinematika maju menggunakan persamaan kinematika robot untuk menghitung posisi efektor akhir dari nilai yang ditentukan untuk parameter bersama [1]. Proses kebalikan yang menghitung parameter bersama yang mencapai posisi tertentu dari end-effector dikenal sebagai kinematika terbalik. Dimensi robot dan persamaan kinematika menentukan volume ruang yang bisa dijangkau oleh robot, yang dikenal sebagai ruang kerjanya [2][3].

Pemakaian teknologi robotika ini dengan tujuan mempermudah kegiatan sehari-hari. Salah satu kegiatan yang dapat dilakukan oleh robot lengan yaitu adalah proses pemindahan barang dari satu tempat ke tempat yang lain. Pada pemindahan barang yang dilakukan manusia mempertimbangkan beratnya barang, jumlah barang, jarak perpindahan dan tenaga manusia yang dibutuhkan [4] (Fajar, 2013). Semakin berat dan semakin banyak barang, atau semakin jauh jarak perpindahan yang akan dilakukan maka tenaga manusia yang dibutuhkan untuk melakukan perpindahan barang akan semakin besar. Selain itu ketidakmungkinan tenaga manusia bekerja selama 24 jam juga merupakan faktor yang memengaruhi tingkat efektifitas serta kualitas kegiatan tersebut [5].

Berdasarkan latar belakang permasalahan tersebut dibutuhkan sebuah robot lengan yang mampu melakukan proses perpindahan barang dari satu tempat ke tempat lain sehingga diharapkan mampu mempermudah kegiatan pemindahan barang yang dilakukan serta meningkatkan tingkat efektifitas baik dalam hal waktu, tenaga maupun kualitas dari suatu kegiatan [6]. 


\section{TEORI PENUNJANG}

Adapun teori penunjang yang dipakai dalam pembuatan Penelitian ini akan terbagi dalam beberapa hal yaitu konstruksi Robot Lengan dan sistem kerja lengan robot, cara kerja sensor warna, cara kerja motor servo, cara kerja reed switch untuk deteksi perputaran robot pada alamatnya.

\section{A. Robot Lengan dan prinsip kerjanya}

Robot merupakan salah satu alat bantu yang dalam kondisi tertentu sangat diperlukan dalam industri. Diantara robot yang sering digunakan dalam dunia industri adalah robot lengan. Robot lengan diharapkan dapat diprogram ulang secara fleksibel oleh pengguna, maka kita membutuhkan antarmuka antara robot lengan dengan pengguna melalui komputer. [9]

Robot lengan adalah sebuah manipulator dengan tiga atau lebih sumbu, yang dikontrol secara otomatis, yang dapat diprogram ulang dengan banyak tujuan. Manipulator adalah suatu struktur mekanik yang terdiri atas beberapa badan yang kaku (link), yang dihubungkan dengan sendi (joint). Manipulator terdiri atas lengan (arm) yang melakukan gerakan, pergelangan (wrist) yang memberikan kecekatan serta end effector yang melakukan tugas yang diinginkan, seperti misalnya gripper yang bisa dilihat pada gambar 1 yaitu bagian - bagian Robot Lengan [10]. Kinerja tiap lengan mengadopsi dari kinerja bagian pengungkit yang bisa dilihat pada gambar 2 yaitu bagian pengungkit. Pesawat sederhana memudahkan manusia untuk melakukan pekerjaannya.

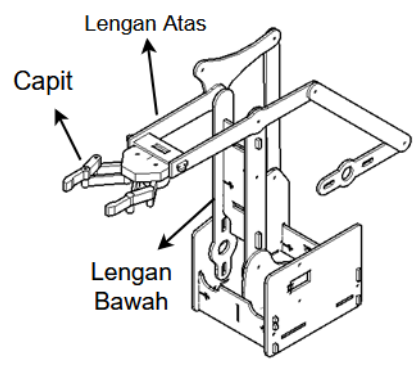

Gambar. 1. Bagian-bagian Robot Lengan

Berdasarkan prinsip kerjanya, pesawat sederhana dibedakan menjadi empat, yaitu: tuas atau pengungkit, bidang miring, katrol, dan roda berporos. Pada lengan robot ini menggunakan sistem pesawat sederhana jenis yaitu tuas golongan 1 dimana titik tumpu berada ditengah, diantara titik kuasa dan titik beban. Terdapat tiga titik utama pada pengungkit ketika kita akan mengungkit sebuah benda, yaitu titik beban (w), titik tumpu (T), dan titikkuasa (F) [7].

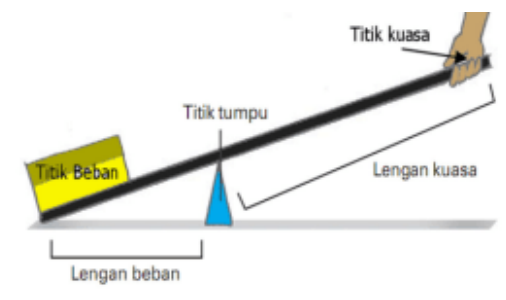

Gambar. 2. Bagian Pengungkit
Beban merupakan berat benda yang diungkit atau diangkat. Kuasa merupakan gaya yang diberikan ketika mengungkit sebuah benda. Lengan beban merupaan jarak antara titik tumpu dengan beban. Sedangkan lengan kuasa sendiri merupakan jarak antara titik tumpu degan kuasa. Hubungan antara beban, kuasa, lengan beban, dan lengan kuasa terlihat sebagai berikut.

$$
\begin{aligned}
& W \times L_{b}=F \times L_{k} \\
& K M=\frac{W}{F}=\frac{L_{k}}{L_{b}}
\end{aligned}
$$

Keterangan :

$\mathrm{W}$ : beban yang diangkat (Newton)

$\mathrm{F}$ : kuasa untuk mengangkat beban (Newton)

$\mathrm{L}_{\mathrm{b}}$ : lengan beban (meter)

$\mathrm{L}_{\mathrm{k}}$ : lengan kuasa (meter)

$\mathrm{KM}$ : keuntungan mekanik

Pada gambar 3 menunjukan bagian bagian lengan robot yang mengaplikasikan system kerja pesawat sederhana. Dimana pada gambar menunjukkan bahwatitik tumpu berada diantara lengan beban dan lengan kuasa sehingga dapat dikatakan sebagai pesawat sederhana golongan 1 .

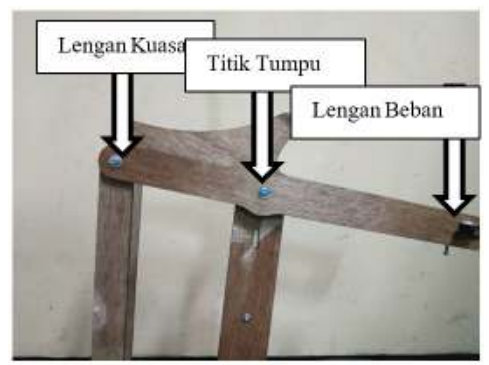

Gambar. 3. Bagian pada Lengan Atas

Pada gambar 4 terlihat posisi titik tumpu lengan kuasa dan lengan beban pada lengan atas robot lengan. Keuntungan mekanis (KM) dapat diartikan sebagai perbandingan antara beban dengan kuasa atau perbandingan antara lengan kuasa dengan lengan beban.

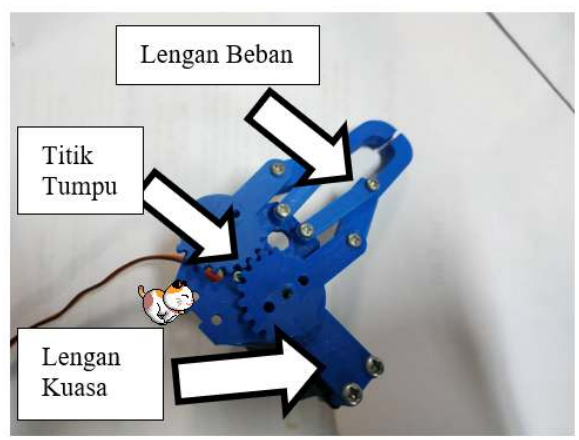

Gambar. 4. Bagian pada Capit Robot

Lengan robot yang akan dibuat menggunakan motor servo dengan torsi sebesar $13 \mathrm{~kg}$, dimana dengan torsi yang telah dimiliki dapat mencari berapa gaya yang dikeluarkan oleh lengan robot. Gaya yang dihasilkan oleh motor servo harus 
lebih besar dari pada gaya yang dibutuhkan oleh lengan kuasa agar lengan robot dapat mengangkat beban yang diangkat oleh robot lengan.

\section{B. Kinematika Robot Lengan 2 Sendi}

Kinematika Robot Lengan yang dipakai adalah dengan konfigurasi robot lengan 2 sendi yang bisa terlihat pada gambar 5 dimana panjang lengan dilambangkan dengan huruf $l$, sedangkan titik sudut lengan robot dilambangkan dengan huruf $j$. Sudut $\theta 1$ dan sudut $\theta 2$ diukur dari titik sumbu $x$ terhadap lengan robot [7]. Apabila variabel yang diketahui adalah besar sudut $(\theta)$, maka untuk mendapatkan kedudukan ujung lengan atau end effector yang dinyatakan sebagai $\mathrm{P}=(x, y)$ adalah dengan menggunakan analisis kinematik maju.

Pada lengan robot pemilah warna ini hanya menggunakan analisi forward kinematic untuk menentukan titik end effector lengan yang berupa gripper terhadap titik bidang miring dan tempat untuk penempatan botol berwarna.

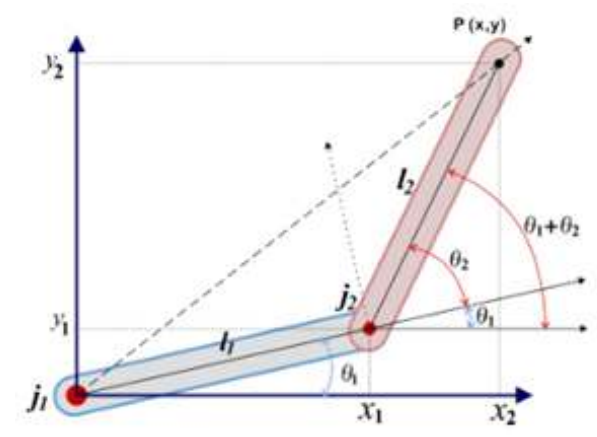

Gambar. 5. Konfigurasi Robot Lengan Dua Sendi

Pada lengan robot penyortir yang dibuat menggunakan perhitungan forward kinematik 2 DOF untuk menentukan titiknya. Berikut merupakan uraian dari perhitungan kinematika maju:

$$
\begin{aligned}
& x l=l 1 \cdot \cos \theta 1+l 2 \cdot \cos (\theta 1+\theta 2) \\
& y l=l 1 \cdot \sin \theta 1+l 2 \cdot \sin (\theta 1+\theta 2)
\end{aligned}
$$

Keterangan:

$\mathrm{x} 1$ : Titik x lengan 1 ; y1 : Titik y lengan 1

11 : Panjang lengan bawah; 12 : Panjang lengan atas

$(\theta 1)$ : Sudut lengan bawah terhadap sumbu $\mathrm{x}$

$(\theta 2)$ : Sudut lengan atas terhadap lengan bawah

\section{Deteksi Warna pada Suatu Objek Sensor Warna}

Sensor adalah alat untuk mendeteksi atau mengukur sesuatu, yang digunakan untuk mengubah variasi mekanis, magnetis, panas, sinar dan kimia menjadi tegangan dan arus listrik. Dalam robot lengan pendeteksi warna ini menggunakan sensor warna yang mengubah intensitas cahaya menjadi tegangan. Dimana pada alat ini sensor warna berfungsi menyerupai mata yang kemudian diolah oleh mikrokontroller sebagai otaknya.

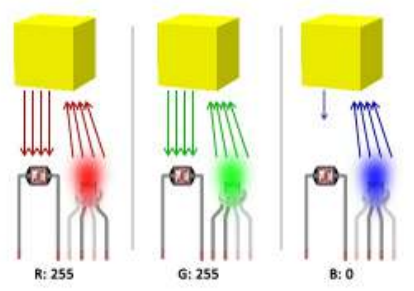

Gambar. 6. Sensor Warna

Pada gambar 6 merupakan rangkaian sensor warna dengan memanfaatkan LED RGB dan resistor LDR. Pada gambar diatas terlihat bahwa posisi LDR harus lebih tinggi dibandingkan LED RGB dikarenakan supaya nilai dari pantulan cahaya tidak terpengaruh oleh cahaya LDR yang langsung mengarah ke LDR.

\section{Metode Dan Inti Penelitian}

Pembuatan sistem perangkat keras (hardware) terbagi menjadi 2 kelompok, yaitu pembuatan sistem perangkat keras mekanik dan pembuatan sistem perangkat keras elektronik. Metode dan inti penelitian pada bagian ini akan terbagi menjadi 2 bagian yaitu perancangan perangkat keras yang dibagi menjadi Perancangan perangkat mekanik dan perancangan perangkat elektronika.

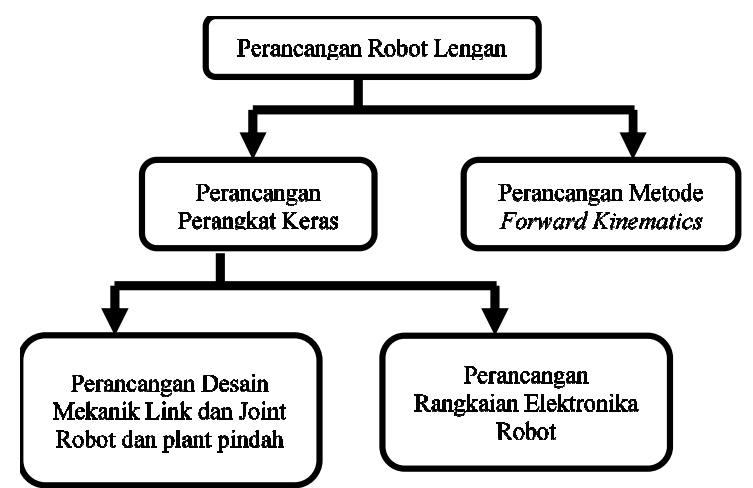

Gambar. 7. Blok Diagram Perancangan Robot Lengan

\section{A. Perancangan Desain Mekanik Link dan Joint Robot}

Berikut adalah komponen-komponen mekanik yang mempunyai peranan penting dalam membangun system dimana desain mekanik robot perangkat lunak komputer CAD untuk menggambar 2 dimensi dan 3 dimensi yang dikembangkan oleh Autodesk [8].

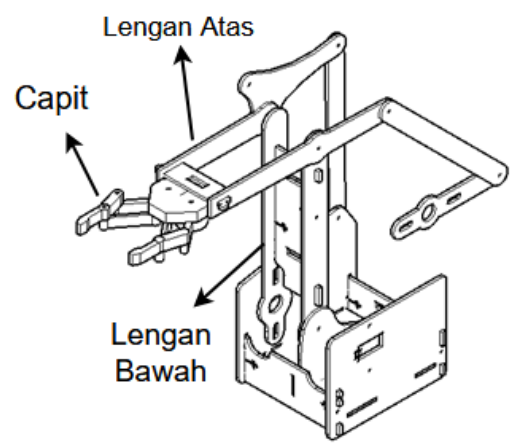

Gambar. 8. Lengan Robot yang Dibuat 
Desain Lengan robot pada gambar 8 merupakan desain untuk bagian badan robot, lengan atas robot, dan lengan bawah lengan robot. Desain pada gambar 8 yang akan terpecah pada ukuran lengan atas, bawah dan capit robot.

Capit robot pada gambar 9 pada saat posisi terbuka memiliki lebar $48 \mathrm{~mm}$, dengan Panjang mencapai $90 \mathrm{~mm}$. Tampak depan saat posisi capit terbuka, terlihat lebar servo mencapai $28 \mathrm{~mm}$.

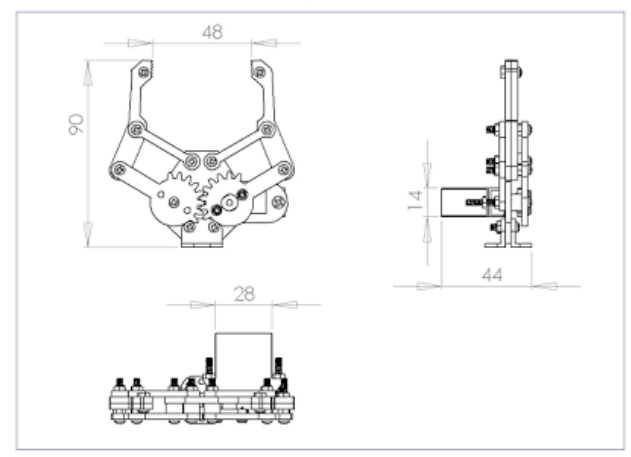

Gambar. 9. Capit Robot yang Dibuat

Sedangkan tampak samping servo memiliki ketebalan mencapai $14 \mathrm{~mm}$, dengan tinggi dari bagian atas servo hingga bagian bawah capit robot memiliki tinggi mencapai $44 \mathrm{~mm}$.

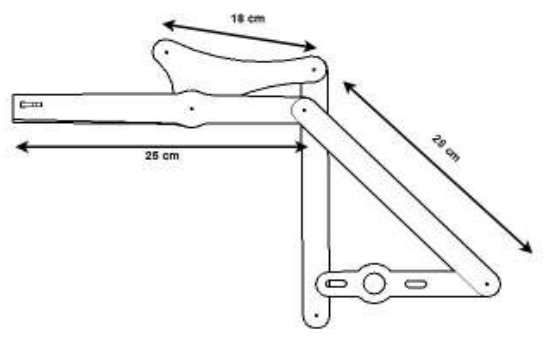

Gambar. 10. Lengan Atas Robot

Kemudian dibuat Lengan atas robot Pada gambar 10 merupakan keseluruhan lengan robot yang telah dirangkai menjadi satu.

Pada bagian depan merupakan bagian lengan atas yang nantinya akan terhubung dengan capit memiliki panjang 30 $\mathrm{cm}$ dan bagian atas merupakan penghubung antara lengan atas bagian depan dan bagian belakang dengan memiliki Panjang $18 \mathrm{~cm}$. Lengan atas bagian belakang memiliki panjang $28 \mathrm{~cm}$ yang berfungsi menghubungkan lengan atas dengan bagian servo. Untuk lengan atas yang dihubungkan pada servo sebagai penggerak keatas dan bawah memiliki panjang $18 \mathrm{~cm}$.

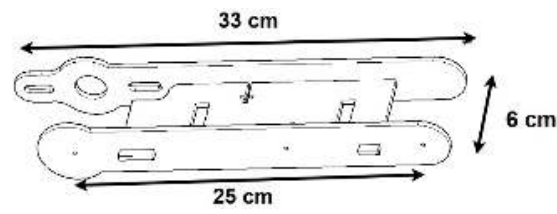

Gambar. 11. Lengan Bawah Robot
Pada gambar 11 terlihat masing masing panjang ukuran untuk lengan bawah. Lengan bawah memiliki 3 bagian, untuk bagian lengan bawah yang terhubung dengan servo memiliki Panjang $33 \mathrm{~cm}$, sedangkan bagian lainnya terhubung pada bagian bawah penampang servo kontinyu, dengan memiliki Panjang $30 \mathrm{~cm}$. Bagian badan pada badan lengan robot pada gambar 12 yang digunakan merupakan adaptasi dari lengan robot Me Arm dengan sedikit modifikasi bentuk dan ukuran. Bagian badan robot yang digunakan menggunkaan bahan kayu karena ringan dan mudah didapatkan dipasaran.

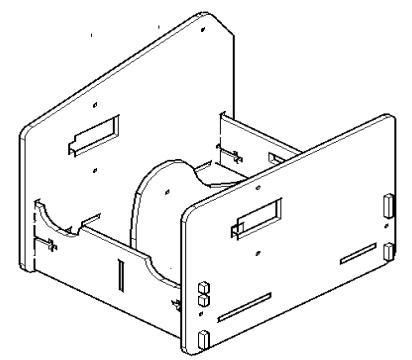

Gambar. 12. Badan Lengan Robot

Demikian bagian - bagian tersebut yang dimulai dari Capit, lengan atas, lengan bawah dan badan lengan dibuat dengan perbandingan 1:15 yang diadopsi dari konstruksi robot Me Arm pada umumnya.

\section{B. Pembuatan Rangkaian Elektronik}

Pembuatan Perangkat Keras Elektronik tediri dari beberapa motor servo dan sensor warna. Berikut meupakan diagram blok dari lengan robot pemilah botol berwarna. Dapat dilihat pada gambar 13.

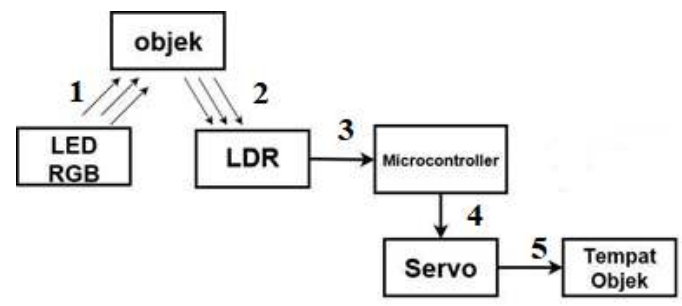

Gambar. 13. Tempat Sensor Warna

Pada gambar 13 menunjukkan diagram blok secara keseluruhan dari cara kerja lengan robot pemilah warna dengan bantuan lengan robot. pertama-tama Input Device ini terdiri dari sensor warna yang terdiri dari LED RGB dan resitor LDR yang diprogram Arduino. Input Device digunakan untukmembaca data yang berisi nilai resistansi resistor LDR yang berasal dari pantulan cahaya LED RGB pada objek. Hal ini berguna untuk mengetahui apakkah nilai sesuai dengan hasil yang telah dikalibrasikan.

Cara kerja Sistem lengan robot pemilah objek berwarna. Pertama tama objek berwarna akan ditaruh pada tempat dimana terdapat sensor warna didalamnya, setelah objek berwarna tersebut berada pada tempat sensor warna, maka dengan sendirinya sensor warna akan mendeteksi warna dari objek tersebut. Dimana sensor warna tersebut terdiri dari LED RGB dan LDR. Setelah warna terdeteksi, maka hasil 
dari pembacaan resistansi LDR tersebut merupakan inputan yang untuk kemudian dikirim ke Arduino. Dimana masing masing warna telah memiliki hasil resistansi masing masing untuk warna merah, hijau, dan biru. Masing masing objek akan memiliki hasil resistansi yang berbeda beda. Dimana nilai dari resistansi tersebut diketahui melalui hasil kalibrasi sensor warna yang telah dilakukan sebelumnya. Setelah mengetahui hasil masing masing resistansi untuk 9 warna, maka hasil tersebut diinputkan ke Arduino untuk kemudian hasilnya dicocokan dengan hasil pendeteksian warna oleh LDR pada tahap selanjutnya.

Setelah warna diketahui maka mikrokontroler akan menghitung warna tersebut, dan kemudian memerintahkan servo untuk bergerak. Pergerakan servo juga telah diinputkan sebelumnya, dimana masing masing warna akan memerintahkan servo untuk bergerak pada tempat yang berbeda beda. Setelah servo bergerak, servo tersebut akan bergerak membawa lengan robot dari tempat peristirahatan lengan untuk kemudian menuju tempat sensor warna mendeteksi objek, kemudian objek akan diangkat dan dipindahkan menuju tempat yang telah disesuaikan. Masing masing servo yang dipasang pada masing masing sendi lengan robot akan bergerak satu persatu sesuai program yang telah diberikan, dimana masing masing warna yang terdeteksi memiliki perintah yang berbeda beda untuk pergerakan sendinya.

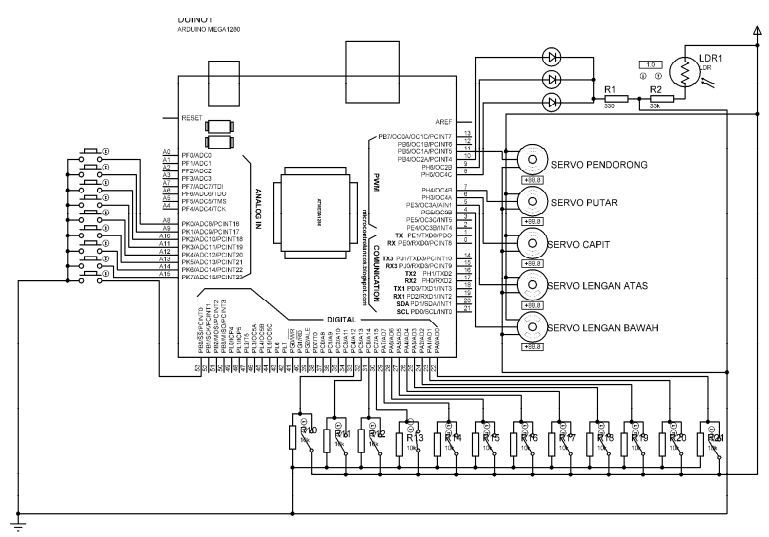

Gambar. 14. Wiring Arduino - Semua Komponen

Setelah objek ditaruh pada tempat yang sesuai, maka kemudian lengan robot tersebut akan bergerak kembali menuju titik tempat peristirahatan lengan robot pada posisi awal. Secara lengkap gambar dan rangkaian pada gambar 14.

\section{Pembuatan Metode Kinematika Maju.}

Kinematika maju atau forward kinematic yang berada pada gambar 15 merupakan analisi kinematik agar mendapatkan posisi titik koordinat kartesian $\mathrm{P}(\mathrm{x}, \mathrm{y}, \mathrm{z})$ jika yang diketahui besar sudut tiap sendi $(\theta)$. Sedangkan kinetik balikan atau invers kinematic adalah analisis kinematik agar mendapatkan besar sudut angular tiap sendi $(\theta)$ jika yang diketahui titik koordinat $\mathrm{P}(\mathrm{x}, \mathrm{y}, \mathrm{z})$.

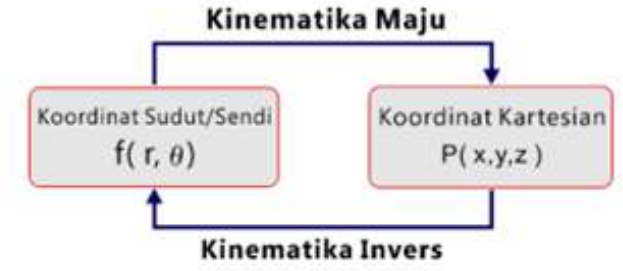

Gambar. 15. Kinematika Maju dan Kinematika Invers

Secara umum forward kinematic adalah memberikan masukan sudut pada tiap-tiap motor servo setelah itu kita dapatkan posisi end-effector. Perancangan forward kinematic dilakukan dengan menghitung terlebih dahulu Homogenus matrik semua link [9].

$$
\begin{aligned}
T_{2}^{0}=A_{1} \cdot A_{2} & =\left[\begin{array}{cccc}
\cos \left(\theta_{1}+\theta_{2}\right. & -\sin \left(\theta_{1}+\theta_{2}\right) & 0 & a_{1} \cos \left(\theta_{1}\right) \\
\sin \left(\theta_{1}+\theta_{2}\right) & \cos \left(\theta_{1}+\theta_{2}\right) & 0 & a_{2} \sin \left(\theta_{2}\right) \\
0 & 0 & 1 & 0 \\
0 & 0 & 0 & 1
\end{array}\right] \\
T_{2}^{0}=A_{1} \cdot A_{2} & =\left[\begin{array}{cccc}
\cos \left(\theta_{1}+\theta_{2}\right. & -\sin \left(\theta_{1}+\theta_{2}\right) & 0 & l 1 \cos \left(\theta_{1}\right)+l 2 \cos \left(\theta_{1}+\theta_{2}\right) \\
\sin \left(\theta_{1}+\theta_{2}\right) & \cos \left(\theta_{1}+\theta_{2}\right) & 0 & l 1 \sin \left(\theta_{1}\right)+l 2 \sin \left(\theta_{1}+\theta_{2}\right) \\
0 & 0 & 1 & 0 \\
0 & 0 & 0 & 1
\end{array}\right] \\
P_{x} & =l 1 \cos \left(\theta_{1}\right)+l 2 \cos \left(\theta_{1}+\theta_{2}\right) \\
P_{y} & =l 1 \sin \left(\theta_{1}\right)+l 2 \sin \left(\theta_{1}+\theta_{2}\right) \\
P_{z} & =0
\end{aligned}
$$

Matrik forward memberikan informasi orientasi dan posisi dari end-effector. Kita lihat pada persamaan diatas posisi koordinat (Px,Py) end-effector dapat kita hitung dengan memberikan masukan sudut pada motor servo untuk setiap link. Kemudian dibantu dengan rumus kinematika maju yang telah ditulis pada rumus (1).

Pada hasil perhitungan kinematika forward saat posisi lengan robot beristirahat. sebagai berikut dimana $x=$ Titik $x$ end effector dan $\mathrm{y}=$ Titik y end effector, dengan pengamatan pada gambar Sudut lengan bawah sebesar $90^{\circ}$ yang disebut $\theta 1$, sedangkan Sudut lengan atas sebesar $230^{\circ}$ yang disebut $\theta 2$.

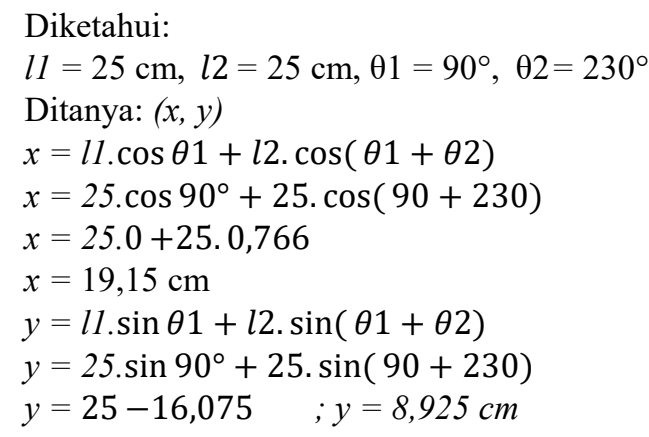

Untuk pembuktian perhitungan diatas dapat terlihat pada gambar gambar 16 dimana bisa diukur pada posisi istirahat lengan robot. 


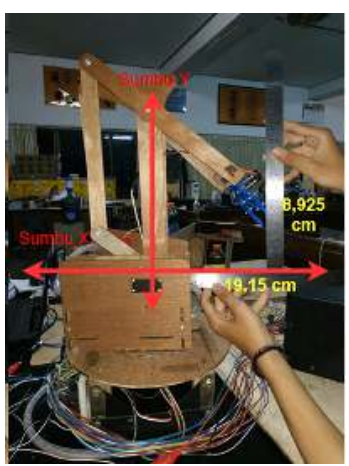

Gambar. 16. Posisi Istirahat Lengan Robot

Untuk mengambil botol dibutuhkan suatu perhitungan yang bisa dan dapat dilihat pada gambar 17.

\section{Diketahui:}

$l 1=25 \mathrm{~cm}, l 2=25 \mathrm{~cm}, \theta 1=45^{\circ}, \theta 2=270^{\circ}$

Ditanya: $(x, y)$

$x=l 1 \cdot \cos \theta 1+l 2 \cdot \cos (\theta 1+\theta 2)$

$x=25 \cdot \cos 45^{\circ}+25 \cdot \cos \left(45^{\circ}+270^{\circ}\right)$

$x=25 \cdot \frac{1}{2} \sqrt{2}+25 \cdot \frac{1}{2} \sqrt{2}$

$x=17.68+17.68$

$x=35.35 \mathrm{~cm}$

$y=l 1 \cdot \sin \theta 1+l 2 \cdot \sin (\theta 1+\theta 2)$

$y=25 \cdot \sin 45^{\circ}+25 \cdot \sin \left(45^{\circ}+270^{\circ}\right)$

$y=25 \cdot \frac{1}{2} \sqrt{2}-25 \cdot \frac{1}{2} \sqrt{2} \quad y=0 \mathrm{~cm}$

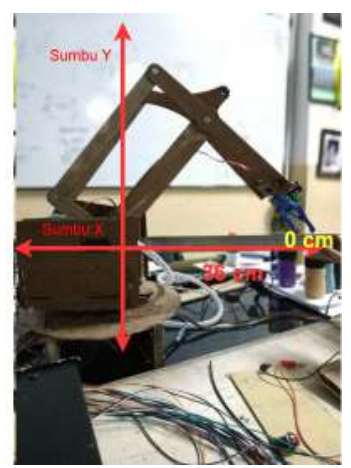

Gambar. 17. Posisi Ambil Barang

Untuk posisi robot dalam membawa barang atau sebuah object botol bisa dihitung dan dilihat pada gambar 18 dengan perhitungan berikut:

\section{Diketahui:}

$l 1=25 \mathrm{~cm}, l 2=25 \mathrm{~cm}, \theta 1=90^{\circ}, \theta 2=290^{\circ}$

Ditanya: $(x, y)$

$x=l 1 \cdot \cos \theta 1+l 2 \cdot \cos (\theta 1+\theta 2)$

$x=25 \cdot \cos 90^{\circ}+25 \cdot \cos (90+290)$

$x=25.0+25.0,93$

$x=25.0,93 ; x=23,49 \mathrm{~cm}$

$y=l 1 . \sin \theta 1+l 2 \cdot \sin (\theta 1+\theta 2)$

$y=25 \cdot \sin 90^{\circ}+25 \cdot \sin \left(90^{\circ}+290^{\circ}\right)$

$y=25.1+8,55 \quad y=33,55 \mathrm{~cm}$

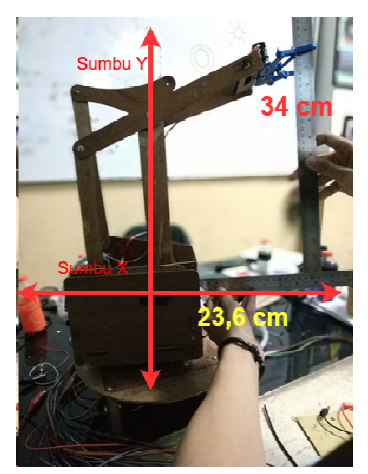

Gambar. 18. Posisi membawa barang

Untuk pembuktian perhitungan diatas dapat terlihat pada gambar gambar 18 dimana bisa diukur pada posisi membawa barang pada lengan robot.

\section{Perancangan Perangkat Lunak}

Pada perancangan perangkat lunak terdapat beberapa hal yang harus dipersiapkan sebelum program proses dibuat. Mempersiapkan warna yang nantinya dimasukkan untuk dapat dideteksi oleh sensor warna yang akan dibuat untuk kemudian dikalibrasikan pada sensor warna yang telah dibuat. Hasil nilai kalibrasi yang telah didapatkan nantinya akan dimasukkan pada program utama yang dijalankan.
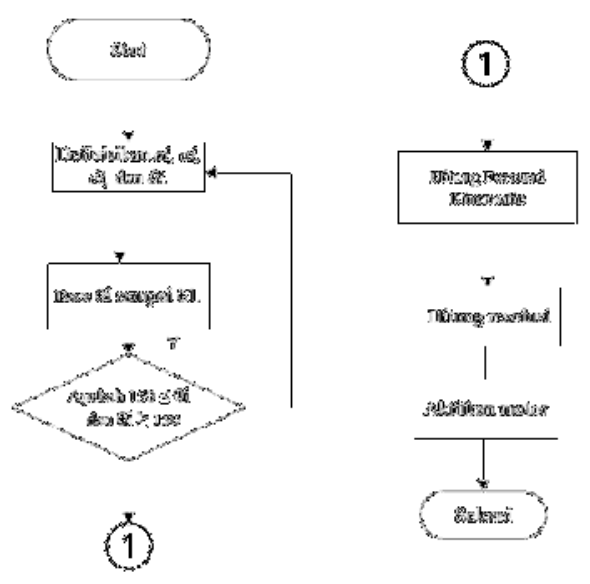

Gambar. 19. Posisi membawa barang

Setelah nilai dari sensor warna dikalibrasi maka bisa masuk pada blok diagram seperti pada gambar 19 dimana mulai menentukan koordinat untuk menentukan nilai $\mathrm{x}$ dan nilai y yang digunakan pada lengan robot.

\section{HASIL EKSPERIMEN DAN PENELITIAN}

Pada bab ini dijelaskan tentang uji coba mesin pengering pakaian. Tahap uji coba dibagi menjadi 3 hal mulai dari hal mekanik, elektronik dan tujuan utama, yaitu hasil uji coba dalam pemilah botol berwarna.

\section{A. Uji Coba Mekanik}

Dalam uji coba mekanik ini akan menampilkan beberapa hasil data uji coba yang telah diperoleh dari percobaan yang telah dilakukan untuk mengetahui ruang kerja perangkat keras mekanik yang telah dibuat yaitu berupa lengan robot. 
TABEL I

Uji Coba Pengukuran Sudut Pergerakan Servo

\begin{tabular}{lcccccc}
\hline \hline \multirow{2}{*}{ Bagian Lengan Robot } & \multicolumn{2}{c}{ Sudut } & \multicolumn{2}{c}{ Sudut } & \multicolumn{2}{c}{ Selisih } \\
& Ideal & \multicolumn{2}{c}{ Robot } & & \\
& (a) & (b) & (a) & (b) & (a) & (b) \\
\hline Servo Base & $0^{\circ}$ & $360^{\circ}$ & $0^{\circ}$ & $360^{\circ}$ & $0^{\circ}$ & $0^{\circ}$ \\
Servo Capit & $0^{\circ}$ & $180^{\circ}$ & $105^{\circ}$ & $150^{\circ}$ & $105^{\circ}$ & $30^{\circ}$ \\
Servo Lengan Atas & $0^{\circ}$ & $180^{\circ}$ & $0^{\circ}$ & $60^{\circ}$ & $0^{\circ}$ & $120^{\circ}$ \\
Servo Lengan Bawah & $0^{\circ}$ & $180^{\circ}$ & $0^{\circ}$ & $45^{\circ}$ & $0^{\circ}$ & $135^{\circ}$ \\
Servo Pendorong & $0^{\circ}$ & $180^{\circ}$ & $0^{\circ}$ & $45^{\circ}$ & $0^{\circ}$ & $135^{\circ}$ \\
\hline \hline
\end{tabular}

Pada tabel 1 diatas dapat terlihat sudut normal untuk masing masing servo pada bagian masing masing sendi lengan robot yang dibuat. Untuk bagian base lengan robot diatas menggunakan servo kontinyu sehingga jangkauan sudut nya antara $0^{\circ}$ hingga $360^{\circ}$. Dan sisanya menggunakan standart servo dengan jangkauan sudut $0^{\circ}$ hingga $180^{\circ}$.

Setelah mengetahui nilai sudut ideal pada masing masing sendi pada lengan robot, selanjutnya penulis akan mencari titik daripada end effector dengan metode forward kinematic.

TABEL II

PERCOBAAN FORWARD KINEMATIK LENGAN ROBOT

\begin{tabular}{lccccc}
\hline \hline No & $\boldsymbol{\theta 1}$ & $\boldsymbol{\theta 2}$ & $\mathbf{P x}$ & Py & Kondisi Lengan \\
\hline 1. & $90^{\circ}$ & $230^{\circ}$ & $19,15 \mathrm{~cm}$ & $8,925 \mathrm{~cm}$ & Istirahat \\
2. & $45^{\circ}$ & $270^{\circ}$ & $35.35 \mathrm{~cm}$ & $0 \mathrm{~cm}$ & Ambil Botol \\
3. & $90^{\circ}$ & $290^{\circ}$ & $23,49 \mathrm{~cm}$ & $33,55 \mathrm{~cm}$ & Angkat Botol \\
\hline \hline
\end{tabular}

Pada tabel 2 diatas merupakan hasil perhitungan dari percobaan forward kinematic pada lengan robot dimana lengan kondisi robot bisa dikategorikan pada kondisi istirahat, kondisi lengan robot untuk ambil beban dan mengangkat beban.

\section{B. Uji Coba Elektronik}

Pengujian dalam hal elektronik ini akan menguji pada besar nilai arus yang dibutuhkan untuk menggerakan motor servo saat dengan beban dan tanpa beban.

TABEL III

PENGUKURAn ARUS YANG MENGALIR PADA SERVo TANPA BEBAN

\begin{tabular}{lccccc}
\hline \hline & $\begin{array}{c}\text { Servo } \\
\text { Base }\end{array}$ & $\begin{array}{c}\text { Servo } \\
\text { Pendorong }\end{array}$ & $\begin{array}{c}\text { Servo } \\
\text { Capit }\end{array}$ & $\begin{array}{c}\text { Lengan } \\
\text { Atas }\end{array}$ & $\begin{array}{c}\text { Lengan } \\
\text { Bawah }\end{array}$ \\
\hline $\begin{array}{l}\text { Arus Saat } \\
\text { Standby }\end{array}$ & 0,007 & $0,0092 \mathrm{~A}$ & 0,0150 & 0,0056 & 0,0148 \\
Arus Saat & $0,12 \mathrm{~A}$ & $0,2 \mathrm{~A}$ & $0,3 \mathrm{~A}$ & $0,4 \mathrm{~A}$ & $0,23 \mathrm{~A}$ \\
Bergerak & & & & & \\
\hline \hline
\end{tabular}

Pada tabel 3 diatas dapat terlihat perolehan nilai arus yang dibutuhkan untuk masing masing servo saat keaadaan standby dan saat keadaan bekerja dan merupakan hasil perolehan nilai arus yang dibutuhkan untuk masing masing servo saat keadaan lengan robot tanpa beban.

TABEL IV

Pengukuran Arus yang Mengalir Pada SERVo Dengan Beban

\begin{tabular}{lccccc}
\hline \hline & $\begin{array}{c}\text { Servo } \\
\text { Base }\end{array}$ & $\begin{array}{c}\text { Servo } \\
\text { Pendorong }\end{array}$ & $\begin{array}{c}\text { Servo } \\
\text { Capit }\end{array}$ & $\begin{array}{c}\text { Lengan } \\
\text { Atas }\end{array}$ & $\begin{array}{c}\text { Lengan } \\
\text { Bawah }\end{array}$ \\
\hline Arus Saat & 0,007 & $0,0092 \mathrm{~A}$ & 0,0150 & 0,0056 & 0,0148 \\
Standby & $\mathrm{A}$ & & $\mathrm{A}$ & $\mathrm{A}$ & $\mathrm{A}$ \\
$\begin{array}{l}\text { Arus Saat } \\
\text { Bergerak }\end{array}$ & 0,15 & $0,2 \mathrm{~A}$ & $0.65 \mathrm{~A}$ & $0,68 \mathrm{~A}$ & $0,3 \mathrm{~A}$ \\
\hline \hline
\end{tabular}

Pada tabel 4 merupakan tabel hasil uji coba arus yang dibutuhkan oleh masing masing motor servo yang digunkan lengan robot saat diberi beban.

\section{Uji Coba Lengan Robot Terhadap Waktu}

Pada bagian ini akan menunjukan hasil uji coba terhadap waktu untuk bebrapa proses pergerakan lengan robot dengan menggunakan beban dan tanpa beban. Data pengujian waktu tempuh dengan berbeban bisa dilihat pada tabel 5 dapat terlihat waktu yang dibutuhkan untuk memindahkan botol dengan beban $100 \mathrm{ml}$ membutuhkan waktu yang lebih lama.

Demikian hasil uji coba yang mencakup uji coba mekanik, uji coba elektronik dan uji coba proses pemindahan sebuah objek berdasarkan waktu.

TABEL V

DATA PENGUJIAN WAKTU TEMPUH TERHADAP WAKTU DENGAN BEBAN

\begin{tabular}{lccccc}
\hline \hline Warna & $\begin{array}{c}\text { Ambil } \\
\text { Barang } \\
\text { (s) }\end{array}$ & $\begin{array}{c}\text { Taruh } \\
\text { Barang } \\
\text { (s) }\end{array}$ & $\begin{array}{c}\text { Kembal } \\
\mathbf{i} \\
\text { (s) }\end{array}$ & $\begin{array}{c}\text { Buang } \\
\text { Barang } \\
(\mathbf{s})\end{array}$ & Total \\
\hline Merah & 11,69 & 21,03 & 1,44 & 25,64 & 33,86 \\
Kuning & 12,09 & 14,52 & 3,10 & 25,70 & 28,99 \\
Hijau & 11,20 & 14,48 & 3,10 & 25,71 & 28,46 \\
Biru & 11,10 & 16,65 & 3,63 & 25,60 & 30,69 \\
Pink & 12,34 & 27,19 & 4,35 & 25,76 & 42,57 \\
Putih & 11,17 & 29,48 & 4,34 & 25,53 & 44,93 \\
Ungu & 11,75 & 34,47 & 4,68 & 25,40 & 50,9 \\
Cyan & 11,79 & 36,88 & 8,00 & 25,38 & 53,12 \\
Hitam & 11,25 & 32,06 & 8,59 & 25,68 & 48,33 \\
\hline \hline
\end{tabular}

\section{KESIMPULAN}

Pada system pengendalian Robot lengan dengan sistem 2 DOF dan metode kinematika maju serta melakukan uji coba maka didapatkan beberapa kesimpulan berikut:

1. Servo kontinyu pada bagian base lengan robot dapat menjangkau sudut maksimal hingga $360^{\circ}$, servo standar pada bagian lengan atas robot dapat menjangkau sudut maksimal hingga $60^{\circ}$, servo standar pada bagian lengan bawah robot dapat menjangkau sudut maksimal hingga $45^{\circ}$, servo standar pada bagian capit robot dapat menjangkau dari sudut $105^{\circ}$ hingga maksimal $150^{\circ}$, dan servo standar pada bagian pendorong dapat menjangkau sudut maksimal hingga $45^{\circ}$.

2. Hasil percobaan untuk menentukan titik koordinat robot sebagai berikut: saat istirahat $(19,15 \mathrm{~cm}, 8,92 \mathrm{~cm})$ dan saat mengangkat botol dan membawa barang $(23,49 \mathrm{~cm}$, $33,55 \mathrm{~cm})$ sedangkan saat mengambil botol $(35,35 \mathrm{~cm}, 0$ $\mathrm{cm})$.

3. Rata rata tingkat keberhasilan lengan robot dalam memilah warna sebesar $74,07 \%$.

4. Rata rata lama proses pemilahan botol berdasarkan warna adalah 40,2 detik untuk satu botol.

\section{DAFTAR PUSTAKA}

[1] Paul, Richard (1981). "Manipulator robot: matematika, pemrograman, dan kontrol: kontrol komputer manipulator robot." MIT Press, Cambridge, Massachusetts. ISBN 978-0-262-16082-7.

[2] JM McCarthy, 1990, Pengantar Kinematika Teoritis, MIT Press, Cambridge, Massachusetts.

[3] John J. Craig, 2004, Pengantar Robotika: Mekanika dan Kontrol (Edisi 3), Prentice-Hall

[4] Fajar, M.,2013.Material Handling. Tersedia melalui: Intelligent of the dawn $<$ muhammadfajar.16mb.com $>$ [Diakses 5 April 2017]. 
JOURNAL OF INFORMATION SYSTEM, GRAPHICS, HOSPITALITY AND TECHNOLOGY

[5] Saefullah,A. Immaniar,D. Reza,A. (2014). Sistem Kontrol Robot Pemindah Barang Menggunakan Aplikasi Android Berbasis Arduino Uno. CCIT Journal . volume 8 no 2, pages 45 - 56. Available: https://raharja.academia.edu/CCITJournal.

[6] Tri, Gita dan Setiawan, E (2014). Robot Lengan Pemindah Barang Berdasarkan Ukurannya Berbasis Mikrokontroler. Eprints Journal . volume 5 no 2, pages 1 - 5. Available: http://eprints.mdp.ac.id/1190/

[7] Charles A. Schuler \& William L. McNamee (1986). Industrial Electronics and Robotics. Singapore : McGraw-Hill.

[8] Ir. H. W. Kwari \& M. Andy Kwari M.Sc. (2000). AutoCAD Designer Bagi Pemula, Penerbit Elex Media Komputindo.

[9] Caysar, Dina, Pengaturan Pergerakan Robot Lengan Smart Arm Robotic Ax-12a Melalui Pendekatan Geometry Based Kinematic Menggunakan Arduino. Studentjournal Vol.2 No. 7, pages 1-8. Availablehttp://elektro.studentjournal.ub.ac.id/index.php/teub/article/ view/340/293

[10] Spong, Mark W. 2007. Robot Dynamics and Control, John Wiley \& Sons. New York. 